HStud 25 (2011)2, 249-265

DOI: 10.1556/HStud.25.2011.2.7

\title{
MISSION ACCOMPLISHED? THE QUESTIONS OF HUNGARY'S INTEGRATION INTO THE EURO-ATLANTIC COMMUNITY
}

\author{
TAMÁS MAGYARICS \\ Eötvös Loránd University \\ Budapest, Hungary
}

\begin{abstract}
Almost each of the political forces and the great majority of the public saw no alternative to Euro-Atlantic integration, that is, accession to NATO and the EC (after 1992 the EU) when Hungary regained its independence in 1990. Membership in both organizations had a number of internal and external implications too. Budapest had to introduce sweeping reforms in practically all walks of life. Thus, for instance, NATO-membership required the establishment of a parliamentary democracy, a functioning market economy, and the observance of civil and human rights. At the same time, Hungary had to sign so-called basic treaties with three of its neighbors in which it again committed itself to peaceful relations and the renunciation of any attempt to regain territories it had lost to the countries affected after the First and the Second World Wars. EU-membership needed even more extensive restructuring of the various Hungarian institutions from law enforcement through finances to social services. In addition, Budapest expected that one of the major dilemmas of reconciling the so-called "Hungarian-Hungarian" question with the "good neighbor" policy would be settled within the framework of European integration. The expectations on behalf of the two sides have only been partially realized yet. Thus, Hungary consistently spends much less on defense than the required level within the Atlantic Alliance; Budapest has been trying to compensate with a relative prominent presence in foreign missions. As for the EU, the threat of a "second class membership" has not disappeared; in fact, after the beginning of the economic recession in 2008 it has even become a more realistic perspective; in reality, Hungary has had to accept a relative loss of power even in Central and Eastern Europe. However, Hungary has a vested interest in a "Strong Europe" (this was the official slogan of Hungary's EU-Presidency during the first six months of 2011) in which "more Europe" should not exclude the country's closer relations with other regions in the world.
\end{abstract}

Keywords: foreign policy, security policy, NATO accession, EU accession, Hungarian relations, good neighbor policy

\section{The Rationale for the Euro-Atlantic Integration after the Transition}

If there was any consensus among the major political forces in Hungary after becoming free and independent again in 1989-90, it was about the - falsely la- 
belled - three "priorities" of Hungarian foreign policy: integration into the Euro-Atlantic community, pursuing a "good neighbor" policy, and establishing close "Hungarian to Hungarian" relationship, that is, intimate links between the Hungarians within Hungary and the Hungarian minorities in the neighboring states. In fact, the widely shared expectation was that the Euro-Atlantic integration would solve the other two outstanding issues as well, especially by "spiritualizing" the borders and by imposing such universal norms on the countries in Central Europe as the observance of human and civil rights, including minority (group) rights. However, this illusion of "pay one and get three" has not materialized yet for reasons which are partly internal and partly external.

Each government's primary obligation is to provide for the security of the territory of the state and the people who live on it. Hungary's security environment is rather curious. On the one hand, geopolitically Hungary is an "indispensable" nation in Central Europe to the extent that it is a link between the West and the East, and the North and the South. However, on the other one, it has a relatively large number of neighbors which have fallen into different categories from a security, economic, political, social, religious, and cultural point of view. Some have become members, just like Hungary, of both NATO and the EU; others have a good chance of becoming members in the short term, and still others can hope to join these organizations in the medium term. There is one, Ukraine, which is not likely to get access to either of these institutions in the foreseeable future. Hungary can also be said to be in the (semi)-periphery of Europe culturally, economically, and historically alike, though geographically it occupies a central position. When the Warsaw Pact ceased to exist, to a large extent because of the bold initiative taken by then PM József Antall, ${ }^{1}$ Hungary found itself in a security "grey area". The multiethnic states around the country started to break up and there was no guarantee whatsoever that the process would be peaceful. Though the separation of the Czechs and the Slovaks was a "velvet divorce", the breakup of Yugoslavia was quite a different story. Besides the obvious military threats - in fact, both the Serb and the Croat militaries repeatedly violated Hungarian airspace and territory during their conflict -, Budapest had to be extremely cautious because of the sizable Hungarian minorities in these two neighboring countries. The situation was made even more sensitive by the fact that Hungary was among the first countries to recognize the independence of Croatia (and by assisting it with small firearms) at a time when hundreds of thousands of ethnic Hungarians were living in Voivodina, and Belgrade might have retaliated any time by moving against them. Moreover, the first freely elected government of Hungary worried about the revival of the Little Entente, that is, a close cooperation of neighbors with relatively substantial Hungarian minorities at the expense of Hungary proper. The security situation in Central Europe further threatened with a potential backlash in the dissolving Soviet Union. In reality, the orthodox Communists' coup in August 1991 sent a 
shiver down the spines of practically everyone in Central Europe. In addition, the violence used by Soviet military forces in some Baltic states evoked painful memories of the role the Red Army had played in the region. In short, the geopolitical situation demanded that Hungary should look for a solution that would resolve these security dilemmas; and the logical and obvious choice was integration into the Euro-Atlantic community.

While taking stock of the different theoretical and practical options, it became incresingly clear that there was no alternative to joining the North Atlantic Treaty Organization. A modified alliance with the Soviet Union/Russia was out of question for obvious reasons, and so was the restructuring of the Warsaw Pact. A Central European regional security framework would have been a paper tiger. A European collective security organization (a sort of OSCE) was likewise deemed to be too weak. In reality, the Cold War tacit agreement between the US and the European allies - that the Europeans were encouraged to build their welfare states under an American security "umbrella" - resulted in a Europe which was not able to handle the hard security challenges on its own - witness the Balkan crises in the 1990s. Relatively speaking, the arguments for neutrality were the strongest of the alternatives to NATO membership; nevertheless, neutrality was not just a matter of unilateral declaration but it was (and is) a matter of security guarantees extended by the great powers. Second, neutrality is much more expensive than membership in a defense alliance, and the Hungarian governments had to take the financial considerations into account as well. The Antall-government also resisted the syren sounds of the Russians: the so-called Kvitsinsky-formula would have stipulated that neither country should join alliances which the other one might find hostile.

\section{Towards NATO-membership}

The US grand strategy vis-à-vis Western Europe after World War II was to de-territorialize, de-nationalize, and de-militarize the area. This mission was given a new lease of life after 1989 in Central and Eastern Europe: all three missions were equally valid here. Moreover, the Clinton Administration developed a new grand strategy towards the Old Continent: to make it "whole and free". The eventual integration of the post-Communist countries into the Atlantic community also appealed to the liberal internationalist impulses in the Americans. The "Perry Principles" incorporated such value criteria as well for membership as democracy and the civilian control of the military, besides a demand for a functioning market economy, settling border disputes, and NATO-compatibility of the militaries. For the Central and Eastern Europeans the primary motif was, of course, to enjoy the benefits of Article V of the Washington Treaty (basically 
American security guarantees) for two reasons. One, as Lech Walesa and Václav Havel explained it to President Clinton, the Poles and the Czechs had been "betrayed and/or abandoned" repeatedly by the European great powers in the past and, therefore, they did not trust them. Two, as the then Polish president metaphorically put it: "A bear is a bear." The underlying message was clear: Russia might be an impotent power for the time being but anything might happen in the future.

Hungary seems to have taken a middle-of-the-road position with regard to a potential revival of Russian expansionism. Poland and the Baltic states were voicing fears from a resurgent Russia most loudly partly on account of their geopolitical position. Paradoxically, a weak central power in Moscow might also have meant an increased level of danger as forces not controlled by the government might have provoked conflicts which potentially could have turned into existential threats given the so-called loose nukes. At the opposite end of the spectrum, there were countries such as the Czech Republic or Slovakia, which did not feel threatened by Moscow in any way. Hungary was - and is - a moderate Atlanticist country; it did not - and does not - blow a potential threat coming from the East out of proportion, but it also calculated, and is calculating, with security threats posed by Russia. The fact is that it is not any more the potential appearance of the Red Army that justifies these feelings but the undeniable attempts by Moscow to regain at least some of its former, predominantly economic, political, and intelligence influence in the region. ${ }^{2}$ Nevertheless, American military presence, if not for anything else but for a Cold War-type "tripwire" effect is preferred by the Central and East Europeans in general and, by the majority of the Hungarians in particular.

It is stating the obvious that NATO is primarily a defense organization. However, one should not discount its political and social dimensions either. The Perry Principles incorporated the requirement of democracy and a functioning market economy as well. In other words: the candidate countries had to "put their houses into order" first. Democracy did not only mean regular parliamentary elections but it also demands the observance of human and civil rights, the proper separation and control of the different branches of government, as well as a strong civil society. In sum: the North Atlantic Organization is based on values and not only interests - this fact explains to a large degree its successes so far. The candidate countries, and even political forces within them which had not been previously famous for observing these rights, accelerated the political and economic transition process in order to qualify for membership as soon as possible. Sometimes, they had to push through painful economic reforms - the Hungarian Bokros-package (named after the then Finance Minister) was one of the best examples. Two State Department officials, Richard Holbrooke and Daniel Fried, and David Lipton (from the Treasury Department) visited Hungary in early 1995 and during the dis- 
cussions with PM Gyula Horn they demanded that Hungary should take certain steps if it wanted to get the support of the US for membership. The Socialist-Free Democrat government, among others, introduced tough financial and economic measures, banned arms sales to "rogue states", and Gyula Horn indicated that they would also like to settle the border and minority issues with Romania and Slovakia. ${ }^{3}$ This latter question was especially important for the Clinton Administration: what they valued was regional stability above everything else. Ultimately, Hungary concluded a series of so-called basic treaties with Ukraine, Romania and Slovakia in the first half of the 1990s despite the fact that Budapest had renounced any territorial claims against its neighbors in the Paris Peace Treaty of 1947. Washington insisted on having this reaffirment of the treaty obligations for fear of "importing" a border dispute in Central Europe.

Nevertheless, different norms were demanded in the strictly military area too: foremost among them is the civilian control of the military. The idea basically goes back to Samuel P. Huntington's suggestion of the dual control over the military forces of the US - specifically by the legislative (Congress) and the executive (the President). ${ }^{4}$ The introduction of the civilian control over the military was a rather slow process in Hungary as it required changing a number of laws and regulations both within the military hierarchy and in the relationship between the President and the National Assembly on one hand, and the military on the other one. Besides, civilian control means transparency to the extent it does not threaten to hurt national security, and the role of civil organizations had also to be found in this complex relationship. In addition to these legal aspects, the real challenge was the modernization and the downsizing of the military at the same time. Modernization did not only incorporate making the equipment used by the Hungarian military compatible with NATO standards, but it also required the changing of the way of thinking of the officers as almost to a man they had been trained in Soviet military facilities and, therefore, by default they had adopted a very different mindframe from that of the officers serving in the various NATO countries. Downsizing had two major aspects: first, some 160,000 people were serving in the military at the end of the 1980s; the number was gradually cut to some 25,000 by now - and the military has become a professional one as well. Second, the military was "top heavy", that is, there were proportionately too many officers and too few NCOs and "rank-and-file", plus too many people were sitting in offices instead of being deployed elsewhere.

\section{The Road to EU-membership}

While NATO was regarded - justly - as primarily a defense organization, the European Union (after the Maastricht Treaty in 1992) was seen a desirable model for 
the Central and East European countries from other points of view. The EU was seen as an entity in which the inter-state relations were resting on cooperation, interdependence, mutual understanding, and civic statehood. The core founding idea of the EU (and its predecessors, the EEC and the EC) was reconciliation, the transformation of neighbors into partners in a collective project. As the initial economic integration was transformed into one with normative powers in almost all walks of life, the expectation was that these norms would prevail in the states in Central and Eastern Europe which had had historically a number of ethnic, religious, political, social, cultural, etc. tensions. In sum: (little) power politics would be replaced with the same reconciliation that had characterized the history of the West Europeans in the decades after 1945.

Hungary, so to speak, wished to kill not two but three birds with one stone with an eventual EU-membership. One of them was further integration into the EuroAtlantic community; the second was the idea that within the EU the borders would be "spiritualized", therefore it would be easier to establish and maintain strong links with the Hungarians living in the neighboring states - and even re-uniting the nation culturally, even if political re-unification was absolutely out of question. A widely shared expectation was that membership in the EU would impose norms and standards in all East and Central European countries which would help the prevailing of a range of human and civil rights, including group rights for minorities. With respect to the latter question the consistent Hungarian position is that strong and satisfied minorities are necessary for stable societies and, in turn, enhance the cohesiveness of the European community too. In fact, this Hungarian view does not enjoy support everywhere in Europe: the individual rights in the name of a liberal ideology are preferred to group rights by the majority of the people on the continent. At that time Hungary wanted to have the protection of minorities incorporated into the "European Constitution" in 2005 but it failed because of the strong opposition by, among others, the French. ${ }^{5}$ The underlying theoretical consideration was a modified version of Rogers Brubaker's so-called triadic nexus, in which the matrix defining the position of a minority group incorporates the following elements: the minority group, the "host" country, and the mother country. The new factor added to these ones is the European Union as a normative political entity, which is both an outside and an "inside" force in this context. ${ }^{6}$ (In fact, former Foreign Minister Kinga Göncz reduced the affected actors in this context to only the local Hungarian leaders and the majority society.) And third, the popular belief was that membership in the EU would bring about a dramatic rise of living standards overnight. In fact, none of these expectations has been realized fully, and this may be the primary cause of a discernible disappointment with a number of people with the EU and, in general, the Euro-Atlantic integration and the increasing popularity of alternative ideas. 
If we take a closer look at this set of expectations, a historical dimension should be introduced. There is no denying that the so-called trauma of Trianon is still shaping the thinking of a large segment of the population in East and Central Europe. It must be emphasized that though, of course, it is primarily connected with the Magyars (Hungarians), the post-World War I peace treaties, especially those which contributed to the creation of formerly non-existent states such as Yugoslavia and Czechoslovakia or enhanced the territories of others even beyond the dreams of most of the people concerned (in Romania), still play a central role in the respective national histories and myths. Therefore, practically no one in Central Europe looks at the various political, economic or social questions as a detached observer and, therefore, they acquire an emotional aspect as well. The Hungarian leaderships wished to move beyond Trianon with the Euro-Atlantic integration but they sometimes bumped into a wall in their endeavors. The "Hungarian card" is still a potent political tool in the hands of radical nationalists in some of the neighboring countries and EU-membership has not put an end to the bitter debates between them and the moderate forces both within and without their countries.

The Hungarian vision of the future of the EU - partly based on the realization that old hostilities die hard - was a "Europe of regions", in which cross-border cooperation in all walks of life prevails over a nationalist approach to international relations. This idea rests on the concept of an enhanced form of cooperation among countries which are located in the same region. Despite the fact that such regional cooperations have been existing within the community (the oldest one being that of the Benelux countries), those who would like to see a more federalized Europe do not watch attempts towards this direction with approval and, sometimes, especially the French leaders (Presidents Chirac and Sarkozy) have even gone public with their reservations about such initiatives. Besides the "Europe of regions", Hungary also had a vested interest in offering membership (or, at least, the perspective of membership) to the neighboring countries. Budapest wished to be "embedded" into the European community and to stop playing the role of a frontier country - which it had been forced to do for centuries. Hungary was afraid of the emergence of new fault lines within Europe; Budapest before the accession and after that consistently supported (and supports) the idea that if a European state wishes to join the Union and if it has met all the preconditions then it should not be excluded from the community.

There was another grand strategic consideration behind Hungary's aspiration to become a member of the EU. Budapest considered a strong and united Europe a vital partner in the transatlantic relationship and, by extension, in all matters global as well. The underlying logic is that the liberal world order, which seems to be the most beneficial to Hungary in spite of its numerous weaknesses, rests on a strong bond between the two sides of the Atlantic Ocean. The strategic interests of 
the US and Europe coincide to a large extent. However, neither of them alone is able to maintain the liberal world order and its institutions; in fact, even the two together are not likely to have the required capabilities to do that, and they badly need partners and/or allies in other regions of the world. However, the US and the EU are the linchpins in this international order. To jump to conclusion: it is in the interest of each European countries to make sure that the EU should be able to play its role on the international stage. Such an EU should be strong and united; despite the fact that Hungary is not one of the large countries, it belongs in the group of medium-sized members, it should do its best to contribute to the emergence of a strong and united Europe.

\section{Hungary in NATO}

Membership in NATO and the EU was considered to be complementary: as former Foreign Minister László Kovács put it, "More Europe does not mean less America". However, the dual membership has not resulted in a "win-win" situation for Hungary all the times; there happened cases when the country's leaders had to face tough decisions. Some of the root causes of this situation are simply beyond the reach of the politicians in Budapest. If we should sum up the situation, we may conclude that Hungary, in fact, wanted to join a different NATO than today's Atlantic Community and, to a lesser extent, a different EU than today's Union. Likewise, the leading members of NATO, especially the US, expected different things that Hungary has been able/willing to deliver so far, and so did some of the most powerful forces in the EU. In other words: some of the expectations on both sides have proved to be misplaced. In a few cases, they have derived from the changed outside conditions and circumstances, and in some other ones one of the sides has failed to live up to the expectations of the other side.

A defense organization such as NATO necessarily measures the performance of its members within the framework of its contribution to the common defense. During the accession talks with Hungary, the Czech Republic and Poland, a large number of experts and officials predominantly in the Realpolitik school repeatedly questioned the candidate countries' capabilities to contribute to the common defense efforts. The Hungarian military was relatively poorly equipped, led by officers who had been trained in the Soviet Union, and the infrastructure (military and civilian alike) was not in the best shape either. The only asset Hungary was bringing to the table was its geopolitical position; more specifically, its vicinity to the Balkans. Hungary's territory was ideal for NATO support activities (a staging area), but besides it there was not too much else Budapest was able to bring to the table. It was more than likely that Hungary would be a consumer of security to a larger degree than a provider of security. 
The size and the equipment of the military were both practically negligible at the time of joining NATO in March 1999. Since then it has turned out that this situation is not likely to change any time in the foreseeable future. As a general European tendency, Hungary has also cut back its defense expenditure; though about two percent of the GDP should be spend on defense-related issues, the current (2011) defense spending is barely one percent of the GDP. The Hungarian government indeed promised to raise defense spending at the time of the accession to this level; then the same promise was made at the Prague Summit in 2002. Next year, then Defense Minister Ferenc Juhász again committed Hungary to achieve the two percent level by 2006 - the series of empty promises somewhat exasperated the political-military-security establishment in the US. (It must be mentioned that Washington has been demanding more resources from practically all the European allies in the name of burden sharing since the Lisbon Summit in 1951.) It is not only the amount of money that has disappointed people in NATO. The organization requires its members to develop homeland defense capabilities; Budapest, especially in the past few years, have not done too much in this field. (This trend may have started to change slowly since May 2011: more attention has been paid to, for instance, the training of reserve forces than previously.) The single most important step towards modernization proved to be rather controversial: the leasing of 14 Gripen fighter aircraft in 2001 has been eating up a substantial portion of the Hungarian defense budget and the value added of a few fighter aircraft to the thousands operated by the other NATO members is questionable. The expeditionary capabilities have also been repeatedly criticized; the Hungarian governments have tried to balance the negative views by deploying the constitutionally allowed maximum number of troops, especially in the Balkans and Afghanistan.

The major problem seems to be the changing mission of NATO. Hungary was doing its best to get admitted into the organization in order to leave a security gray zone and to acquire hard security guarantees against any potential outside threat. Nevertheless, such threats seem to have disappeared and, instead, NATO was evolving into an organization engaged in the creation and defense of zones of stability - and not exclusively military one. This emphasis on "out-of-area" operations do not sit well with the Hungarian political elite and the people at large alike; it is very telling that the East and Central European states, including of course Hungary, were among the most vocal supporters of keeping Article 5 of the Washington Treaty as the core mission of NATO's new strategy accepted in Lisbon in 2010. In general, most of the people in Hungary seem to think of security in the conventional sense and do not accept the extended interpretation of security which is one of the by-products of globalization, which, in turn, is not a popular term among large segments of the population either.

Hungary's position within NATO has been downgraded for outside reasons as well; one may conclude that all of them have been beneficial for the security of the 
country. First and foremost, it seems that the armed conflicts, the ethnic cleansings and wars in the Balkans belong to the past. Hungary was fulfilling an important role in the NATO operations both at the Bosnian and the Kosovo crises. The Taszár air base was instrumental in controlling the airspace over the Western Balkans and it also served as a staging area for troops to be deployed in Southeast Europe. In reality, the Hungarian governments took relatively great risk with this support activity because of the presence of a sizable Hungarian minority in Voivodina. However, after the conclusion of the hostitilies and the beginning of the peacekeeping missions, in which Hungarian military units from military police to engineering ones have been taking place, the Taszár air base was shut down. With the accession of Romania and Bulgaria to NATO, the Atlantic Alliance got access to military facilities (air bases, ports) which are closer to the potential trouble spots. The gradual integration of the countries in Southeast Europe into NATO and the EU means that one of the major potential security threats to Hungary has been eliminated. Moreover, the widely criticized division of labor within NATO has also weakened the American interest in the region. While the US forces bore the brunt of the military operations (for instance, the USAF flew some 70 percent of the approximately 36,000 sorties in Spring 1999), the Europeans gradually took over the peacekeeping tasks. ${ }^{7}$ The end result is that Hungary has become more and more "embedded" into the EU and NATO and, therefore, does not need a special attention in the NATO Headquarters. Hungary has been left on the sidelines during the recent debates over the deployment of elements of the missile defense (MD) system. The Bush Administration was trying to deploy a radar station in the Czech Republic and a number of anti-ballistic missile batteries in Poland. The Obama Administration scrapped these ideas and instead is pushing for a layered defense system with some Patriots in Poland but other elements of the MD are to be constructed in Romania - these two countries seem to be occupying the top spots for the American strategists in East and Central Europe.

The Hungarian contribution to the common defense against the various security challenges is rather modest. Hungary is playing host to a transport wing of a few C-17s at Pápa. The country is supposed to have three 3D radar stations which are integrated into NATO's early warning system; the site of the third one has been in the center of controversies between the environment protectionists and the Ministry of Defense (MoD). At long last it seems that a suitable site has been found and the construction of the third radar station may begin soon. The governments of Hungary have been trying to balance the lower than promised defense budgets and other deficiences in the modernization of the military and the force structure, as well as the poor homeland defense capabilities by sending the constitutionally allowed maximum number of troops $(1,000)$ abroad to the various NATO missions. The NATO leaders publicly express their appreciation of the Hungarian efforts, but privately they repeatedly give voice to their frustration and 
disappointment with the gap between the promises and what actually Budapest has delivered. ${ }^{8}$ In short: Hungary does not seem to have made the passage from a consumer of security to a provider of security yet.

\section{A Second-class Membership in the EU?}

The core strategic goal of EU-membership for Hungary is to get from the "(semi)periphery" of Europe into the core. One may come to conclusion without any exaggeration that this expectation has not been fulfilled yet. For a start, Hungary, together with the other new members in May 2004, did not enjoy all the four freedoms which constitute the pillars of the EU. Though the free movement of the capital and the people was granted, it was only three countries (Ireland, Sweden, and the UK) that opened their labor market (free movement of labor), and the scare of the "Polish plumber" in France and other old members of the EU (free movement of services) is also well-known. Besides, Hungarian agricultural products received only a quarter of the subsidies farmers got for their products in the old member states (although the government was allowed to add an additional 30 percent subsidy out of the state budget). In truth, there were so-called derogations as well: Hungary was allowed to introduce certain measures only after the expiration of a period of time. One of the most sensitive such issues was the free sale of lands; the Hungarian government succeeded in securing a relatively long period in which it was allowed to prevent them from being bought up by foreign nationals. (In fact, there are loopholes in the laws and large portions of lands have been acquired through, for instance, "pocket deals", especially by Austrians in the west of Hungary.)

The first Orbán-government believed that Hungary would join the eurozone in four or five years, by the middle of the 2000s. However, the incoming Socialist-Free Democrat coalition started to put it off; in fact, it had to as Hungary was getting farther and farther away from meeting the Copenhagen criteria. They, among others, require that the national debt should not exceed 60 percent of the GDP; it stood at 53 percent when the first Orbán-government stepped down, and when the second one took office eight years later in the spring of 2010, the debt was above 80 percent. The inflation rate was consistently higher than allowed in the first decade of the 21 st century. At the moment, the official target date is 2020 , but given the troubling consequences of the economic crisis and the subsequent grave financial situation in Ireland, Greece, and Portugal (and similar possible outcomes in other countries, especially Spain and Italy), the future of the euro itself has become less certain than it was a few years ago. Nevertheless, with the so-called economic governance and the European semester, both of which are aimed at imposing tighter control on the economies and finances of the member 
states, one potential consequence may be the emergence of a truly two-speed Europe - "truly" in the sense that the EU is not composed of absolutely equal members even at the moment.

Hungary experienced what dilemmas membership in the EU and NATO might convey. The question was exposed relatively early during the NATO accession talks when François Leotard, the then French Defense Minister made the comment that if one country knocked at the door of NATO, then it practically meant that it knocked at the door of the US. He added that what they really wanted was that the Central European countries would ask for security guarantees from the Western European states. ${ }^{9}$ On the eve of the war on Iraq in early 2003, a number of European leaders expressed their public support of the American position in the question. The rather rude and undiplomatic rebuke arrived immediately: then President Jacques Chirac declared that the participating East and Central European politicians had missed an opportunity to "shut up" and he complained about the defective "upbringing" of these people as well. This patronizing mentality was inherited by Nicholas Sarkozy, who lectured the Visegrad countries on the unity of the EU when the four Central Europeans discussed the possibility of reconciling their positions before certain EU-summits. ${ }^{10}$ (This is a practice regularly exercised by France and Germany, or the Benelux countries.) The message was clear: there are "more equals" in the EU than the rest. This inequality can also be seen on other levels: for example, the currently forming European External Action Service staff is heavily biased in favor of the old members. On a more general level, especially with regard to the Europeans' attitude towards the US and Russia, one can see not so invisible dividing lines: while the Central and East Europeans, on the whole, are more Atlanticist and more skeptical towards Moscow, the Western half of continental Europe, again on the whole, entertains reverse sentiments.

Much hope was pinned on the Schengen-regime in Hungary. Besides being able to enjoy the benefits of the free movement of people, it was also seen as a useful tool in the re-unification of the Hungarian nation culturally and partly economically too. Nevertheless, certain steps taken by the first and second Orbán-governments have raised - basically unfounded - suspicions in some of the neighboring countries. The first such issue was the so-called status law, which would have given a number of rights (including health care, education, etc.) to ethnic Hungarians who lived outside of Hungary. The question was coupled with an inherent suspicion nurtured by a few political forces in the neighboring countries against the center-right political forces in Hungary. Strong protests were triggered in, for instance, Romania when PM József Antall declared that he wished to be the Prime Minister of 15 million Hungarians in spirit. Any mention of the unity of Hungarians within the Carpathian Basin is a red rag to nationalist forces in Slovakia, Ukraine, Romania and Serbia in the first place. Moreover, the center-right political parties in Hungary have always stressed that they supported the cultural, and, 
possibly, political autonomy of the ethnic Hungarians in these countries - if and when the rightful representatives of the Hungarian minorities also shared this strategic goal. In reality, this issue has driven another wedge between the center-right and the left-of-center political forces in Hungary and, unfortunately, this division is mirrored within the Hungarian minorities in the affected countries. On a higher political level, the EU does not support or does not condemn autonomies; it simply refers to these issues to the appropriate countries' competencies. On another level, the great powers out of Realpolitik considerations are not very enthusiastic about the Hungarian efforts at gaining autonomy because they see it as a potential source of instability inside NATO and EU member states.

Another issue which gave rise to criticism from various quarters was the repeated attempts by the first and second Orbán-governments to find, at least, symbolic redress for the grievances of ethnic Hungarians who found themselves outside of Hungary proper after World War I. PM Orbán believes that there is no successful Euro-Atlantic policy without regional stability; while a successful EU integration does not only strengthen regional security and cooperation, but it also creates an opportunity to settle the question of the Hungarians beyond the borders. The first attempt was the introduction of the so-called status law which wished to give preferential treatment to ethnic Magyars who lived outside of the mother country. Though Hungary was not a member of the EU yet at the introduction of the law, the major argument against it was that within the EU - at least nominally - there can be no discrimination between citizens of the community; that is, everyone should enjoy equal rights in all walks of life. Upon assuming power again in 2010, the Orbán-government did not waste time in introducing a bill into the Hungarian National Assembly about National Cohesion. The law itself condemns any attempt directed at assimilation of national minorities; moreover, it reinforces Hungary's commitment to support the efforts of the members and communities of the nation to maintain links with each other and to their natural rights to gain various forms of group autonomies in accordance of the practices accepted in Europe. Next, the National Assembly passed a law on the extension of dual citizenship. As it happened a few days before the parliamentary elections in Slovakia, the law gave another excuse for the nationalists (such as the SNS) to play out the "Magyar card". The law was accepted in the other neighbors without any comments (in fact, it was partly modeled on a similar measure taken by the Romanian legislative). The bone of contention between Budapest and Bratislava is whether the extended dual citizenship law has extraterritorial validity or nor. On one hand, the EU renders all questions related to citizenship under the authority of the members states and, on the other one, quite a few EU-states (Italy, Portugal, Romania, etc.) do have dual citizenship. The real problem seems to be political and historical: certain countries in Central Europe are especially sensitive about citizenship as well as autonomy because they fear that these would be only the first steps to- 
wards secession. (That is the prime reason why Romania and Slovakia do not recognize Kosovo as an independent state; they are afraid of "sanctioning" a precedent.) On a higher level, the opponents to the Hungarian status law and the extended dual citizenship law claim that they are unneccessary because the EU has "spiritualized" the borders (de-territorialized the continent). In addition, they fear that the disputes generated by these measures between EU-members would weaken the cohesion of the community and threaten the realization of the dream of a "Europe whole and free". The measures, especially the latter one, have contributed to the opening of another division line between the ethnic Magyar political parties in Romania, Serbia, Slovakia and Ukraine alike. Moreover, a new alternative appeared in Slovakia in the form of the Hid-Most (Bridge) party, which is a Hungarian-Slovak party and lured away quite a number of votes from the ethnically "pure" Magyar Koalíció Pártja (Party of Hungarian Coalition) at the recent parliamentary elections in Slovakia. There is a possibility that similar ethnically mixed parties will be formed in, for instance, Romania and Serbia and the local Magyar communities will not only be divided along lines mirroring the political spectrum in the mother country, but they will also be split along the lines of promoting "pure" Hungarian parties versus ethnically mixed ones in their "host" countries.

\section{Conclusions}

Hungary has become a member of both NATO and the EU - on paper the single most important goal identified after the fall of communism by the overwhelming majority of the political elite and the people at large alike has been achieved. The integration into the EU and the trans-Atlantic cooperation are two sides on the same coin; neither can be imagined without the other one. Moreover, with the similar integration of most of neighbors and the stabilization of the situation in Southeast Europe the regional circumstances have also improved to a large extent; Hungary has practically been "embedded" in the Euro-Atlantic community. The country does not face any serious or, let alone, existential threat. Budapest has met the bulk of the political, economic, and value standards and norms which were preconditions of accession.

Hungary has benefited enormously from membership in the two organizations. NATO provides the vital security guarantee without which Hungary's domestic and international positions would be unquestionably worse than they are today. At the same time, the normative power of the Alliance should not be discounted either; it urged on Hungary to adopt far-reaching domestic reforms and to conclude important international agreements, especially with some of the neighboring states. However, the successive governments' promise that Hungary would be- 
come a provider of security instead of a consumer of security has not been realized yet despite occasional serious efforts by the troops on the field. The force structure should be further modernized, and so should the capabilities of the military. Hungary has been spending far less on the country's defense capabilities than is expected from her. ${ }^{11}$ Though Budapest is doing relatively well as regards foreign missions, it still has not lived up to the expectations and promises. In a deeper sense, the real problem seems to a divergence between the visions of the future of the Alliance and the threat perception in Washington and most of the European capitals, including Budapest. It does seem that the NATO Hungary wanted to join and the NATO it actually joined are two different organizations. The former was closer to the NATO of the Cold War, that is, a basically territorial defense organization with clear-cut circumstances under which it would take action. The latter one is an organization which is, to some extent, in search of a mission; the "out-of-area" operations and the new, extended concept of security do not mesh so well with the Hungarian ideas of security than the "old" NATO's strategy. The political elite has found it politically too sensitive to initiate a serious public debate on security in a globalized world, and now it would amount to almost a political suicide to divert some of the already scarce resources to defense related issues. Hungary is not alone in this question: most of the European members of NATO have to face a similar situation. Hungary's contribution alone does not make or break the Alliance; nevertheless, Budapest can contribute positively and negatively alike to the emergence of a critical mass and, thus, may influence the future of NATO in the final analysis.

Hungary has completed an important phase of integration into the EU with its Presidency in the first six months of 2011. The professionalism of the different branches of the government which were managing the EU-affairs in cooperation with the appropriate officials in the various EU-institutions from the European Commission to the European Parliament earned high grades from the observers. This recognition of the achievements of Hungary was all the more timely as Hungary had become one of the first "sick men" of Europe in 2008 when the country had to be bailed out by the IMF, the EU and the EBRD. Nevertheless, there are areas in which Hungary cannot claim to be belonging in the core of the EU. One such question is membership in the euro-zone. Though the hasty introduction of the euro is definitely not in the interest of Budapest, the majority expert opinion is that in the medium and long term it would be safer to adopt the euro as a currency for not only financial, but also political reasons. Though the elbow room of the governments to stimulate either demand or supply, or to inflate of deflate the national currency in harmony with the changing economic environment would be more limited that at the moment, the stability of the currency might offset these consequences. Another step towards further integration into the EU is the membership perspective of Hungary's neighbors in the Western Balkans, while Roma- 
nia and Bulgaria are likely to join the Schengen regime in the foreseeable future. At the same time, the Eastern Neighborhood project seems to be suffering setbacks, partly as a consequence of the "Arab Spring" and, thus, the "upgrading" of the Southern Neighborhood policy. The territory between Russia and the EU continues to be a "gray area" - which is not in Hungary's interest. On the other hand, the integration of energy policies within the EU by 2014 as well as the common efforts in Central Europe to diversify energy resorces and transit systems are very promising and advance Hungary's strategic goals. Hungary cannot only contribute to the creation of a "Strong Europe" (which was the Presidency's key message) by furthering European projects, though; a more important contribution is the creation of a strong and stable economic, political and social environment at home.

\section{Notes}

1

See, for instance, Für, Lajos (2003) A Varsói Szerződés végnapjai - magyar szemmel (Budapest: Kairosz Kiadó), 137.

2 On Russia's ambitions see, among others, Bugajski, Janusz (2004) Cold Peace. Russia's New Imperialism (Wesport, CT-London: Praeger); and Lucas, Edward (2009) The New Cold War. Putin's Russia and the Threat to the West (Houndmills, Basingstoke: Palgrave Macmillan).

3 Asmus, Ronald D. (2003) A NATO kapunyitása (Budapest: Zrínyi), 220.

$4 \quad$ Huntington, Samuel P. (1985; first ed. 1957) The Soldier and the State. The Theory and Politics of Civil-Military Relations (Cambridge, MA-London, England: The Belknap Press of Harvard University Press), especially Chapter 7.

5 The EU Stabilization Conference (1995) provided for the observation of minority rights within the context of human rights (Point 5).

6 See Balogh, András (1998) Integráció és nemzeti érdek (Budapest: Kossuth), 26.

7 Lord Robertson in the capacity of the Secretary General of NATO suggested that the European allies should concentrate on three things: capabilities, capabilities, capabilities. The US has been outspending the European allies in defense-related expenditures for decades and, as a result, a capability gap has opened between the US and the Europeans. This gap even grew wider after the conclusion of the Cold War when the Europeans were busy accumulating the so-called peace dividends, which meant deep cuts in defense budgets. Now the common military operations may be at risk because of the capabilities gap - and we have not even discussed the other gap between the threat perceptions in Washington and in most of the European capitals.

8 Perhaps the article that evoked the strongest reactions was Celeste A. Wallander (November/December 2002) 'NATO's Price. Shape Up or Ship Out' Foreign Affairs, Vol. 81, No. 6, 2-8.

9 Asmus, op. cit., 89.

10 The question of cooperation among Czechoslovakia (after January 1, 1993 the Czech Republic and Slovakia), Hungary and Poland has always been disputed. Though at the birth of the Visegrad Three in early 1991 the idea was that the participating countries would be working together and assisting each other in their aspirations to join the Euro-Atlantic institutions, during the actual accession talks to the EU they were sometimes behaving as rivals and not as part- 
ners in some questions. In fact, the only institution established by the Visegrad Four is the Visegrad Fund, which promotes cultural exchange and the like; no formal institutionalized cooperation has been established in other fields. The Visegrad Summits are only informal meetings; the centrifugal forces such as the Hungarian-Slovak relations, the Polish ambitions to become one of the members of the Big 6 of the EU, the Czech skepticism, etc. have proved to be strong enough to prevent the creation of a powerful regional bloc. The real problem is that basic strategic questions concerning the rationale, the goals, and the vision of a common future have never been properly answered.

11 It does not mean that the "input" is more important than the "output"; that is, the amount of money spent on the military itself is not a guarantee that it is spent well. In a broader context, that is one of the most pressing problems with the European allies: there are a lot of duplications, waterheads, bloated bureaucracies, etc. which contribute to the capabilities gap between the US and the European members of NATO. 